$$
\begin{array}{l|l|l}
\text { Jurnal Eksplorasi Akuntansi } & \text { e-ISSN : 2656-3649 (Online) } \\
\text { Vol 3, No 2, Mei 2021, Hal 400-413 } & \text { http://jea.ppj.unp.ac.id/index.php/jea }
\end{array}
$$

\title{
Pengaruh Pertumbuhan Ekonomi, Dana Alokasi Umum, PAD, Sisa Lebih Pembiayaan Anggaran, dan Luas Wilayah Terhadap Belanja Modal Pemerintah Daerah
}

\author{
Alan Sepriadi ${ }^{1 *}$, Erly Mulyani \\ ${ }^{1}$ Jurusan Akuntansi, Fakultas Ekonomi, Universitas Negri Padang \\ ${ }^{2}$ Jurusan Akuntansi, Fakultas Ekonomi, Universitas Negri Padang \\ *Korespondensi: alansepriadi42@gmail.com
}

\begin{abstract}
The purpose of this study was to determine the effect of economic growth, general allocation funds, PAD, excess budget financing and area size on capital expenditures in district / city governments in Bengkulu. The population in this study were districts / cities in Bengkulu which consisted of 10 districts / cities during the 2015-2019 period. The method used in this study was the Jenuh method with the Eviews-9 software. The results of the study indicate that partially the variables of economic growth, general allocation funds, PAD, excess budget financing and area size do not have a significant positive effect on regional spending as an independent variable on capital expenditure in regencies / cities in Bengkulu.
\end{abstract}

Keywords: Economic Growth; General Allocation Funds; PAD; Remaining Budget Financing Excess; Area and Capital Costs

How to cite (APA $6^{\text {th }}$ style)

Sepriadi., A \& Mulyani, E. (2021). Pengaruh Pertumbuhan Ekonomi, Dana Alokasi Umum, Pad, Sisa Lebih Pembiayaan Anggaran, Dan Luas Wilayah Terhadap Belanja Modal Pemerintah Daerah. Jurnal Eksplorasi Akuntansi, 3(2), 400-413.

\section{PENDAHULUAN}

Kebijakan dalam permasalahan otonomi daerah sudah menjadi kewajiban, wewenang, serta hak daerah untuk mengatur dan mengurus daerah otonomnya. Kebijakan tersebut tertuang pada Undang-Undang No. 32 Tahun 2004 tentang Otonomi Daerah. Tujuan adanya pengaturan tentang otonomi daerah tidak lain untuk memberikan kesejahteraan dan meningkatkan mutu pelayanan daerah. APBD sebagai pedoman pencapaian tujuan kesejahteraan masyarakat oleh pemerintah memiliki komponen komponen penting yaitu pembiayaan belanja daerah. Pembiayan belanja daerah terbagi atas 2 bentuk yaitu belanja langsung dan tidak. Perbedan antara belanja langsung dan tidak langsung terletak pada penganggaran pelaksanaan program. Belanja langsung dianggarkan sedangkan belanja tidak langsung tidak berkaitan secara langsung terutama dengan biaya modal.

Belanja modal yang dimaksudkan dalam perencanaan anggaran merupakan pengeluaran yang dimaksudkan untuk dapat menambah aset tetap daerah. Aset tetap ini dapat dimanfaatkan lebih dari 1 tahun periode sehingga mampu untuk menunjang ketersediaan sarana dan prasarana publik. Pengaruh yang diharapkan timbul dari realisasi anggaran belanja 
modal seiring perkembangan sarana dan prasarana publik adalah terdorongnya pertumbuhan ekonomi daerah.

Tabel 1. Rasio Belanja Provinsi Bengkulu

\begin{tabular}{|c|c|c|c|}
\hline Tahun & Provinsi & $\begin{array}{c}\text { Rasio Belanja } \\
\text { Pengawai }\end{array}$ & $\begin{array}{c}\text { Rasio Belanja } \\
\text { Modal }\end{array}$ \\
\hline 2015 & Bengkulu & $42,92 \%$ & $23,27 \%$ \\
\hline 2016 & Bengkulu & $38,95 \%$ & $24,03 \%$ \\
\hline 2017 & Bengkulu & $39,89 \%$ & $20,78 \%$ \\
\hline 2018 & Bengkulu & $40,87 \%$ & $17,23 \%$ \\
\hline 2019 & Bengkulu & $39,87 \%$ & $19,73 \%$ \\
\hline \multicolumn{3}{|c|}{ Sumber : Badan Pusat Statistik(BPS) Provinsi Bengkulu }
\end{tabular}

Fenomena yang terjadi di Provinsi Bengkulu realitanya belanja daerah lebih besar di alokasikan untuk menutupi beban rutin yang tidak dominan dalam pembangunan daerah dikutip melalui data dari BPS pada Provinsi Bengkulu bahwa rasio belanja pegawai lebih mendominasi dari belanja modal pada total anggaran belanja modal. Peneliti mencoba menggali lebih dalam tentang belanja modal yang di lakukan pada kabupaten/kota di Provinsi Bengkulu. Tahun penelitian yang di gunakan adalah tahun 2015-2019. Penelitian yang membahas keterkaitan antara DAU PAD dengan belanja modal telah dilakukan oleh Riviando et.al (2019) pada kabupaten dan kota di propinsi Sumatera Barat. Namun peneliti menemukan bahwa tidak banyak penelitian yang sudah dilakukan mengenai topik ini di Provinsi Bengkulu.

Sehingga peneliti meyakini bahwa penelitian ini akan baik untuk dilakukan dan dapat memberikan sumbangan pengetahuan dan referensi bagi pemerintah daerah setempat nantinya

\section{REVIU LITERATUR DAN HIPOTESIS Agency Theory}

Teori agensi menjelaskan terdapat hubungan yang timbul karena adanya kontrak antara dua belah pihak adalah rakyat (principal) yang memberikan tanggungjawabnya kepada pemerintah (agent) dalam menyediakan jasa atas kepentingan rakyat (Jensen,1976). Dalam teori keagenan pihak agent dan principal terdapat perbedaan kepentingan, dimana agent tidak selalu melakukan perilaku atau tindakan yang terbaik untuk kepentingan principal.

Menurut Yovita pada tahun 2011 menjadikan teori agen bagian dari game theory mempelajari sebuah model kontraktual dimana akan mendorong agent untuk bertindak bagi principal pada saat kepentingan agent bisa saja bertentangan terhadap kepentingan principal. Pihak rakyat (principal) mendelegasikan pertanggungjawabannya atas pengambilan keputusan kepada agent (pemerintah) yang mempunyai tanggungjawab dan wewenang agent dan principal diatur berdasarkan kontrak kerja atas persetujuan bersama.

\section{Belanja Modal}

Menurut Halim (2004) menjelaskan bahwa belanja modal adalah pengeluaran anggaran untuk memperoleh asset tetap dan asset lainnya yang memberikan manfaat lebih dari satu periode akuntansi". (Mardiasmo, 2002) mengungkapkan belanja modal adalah pengeluaran yang digunkan cenderung melebihi satu tahun anggaran dan akan menambah anggaran rutin untuk biaya operasional dan pemeliharaanya. Belanja modal gunakan untuk pembentukan modal". dari penelitian diatas, dapat disimpulkan belanja modal mendatangkan manfaat lebih satu periode dan menambah kekayaan daerah dan aset tersebut yang dimanfaatkan untuk operasional sehari-hari bukan untuk kepentingan publik. 


\section{Pertumbuhan Ekonomi}

Pendapatan perkapita menunjukan seberapa besar perturnbuhan ekonomi suatu daerah. Dengan meningkatnya pertumbuhan ekonomi di harapkan adanya peningkatan pendapatan masyarakat dan peningkatan produksi. Maka pertumbuhan ekonomi memperlihatkan perubahan yang sifatnya kuantitatif dan pengukuran menggunakan data produk domestic penambahan nilai barang dan jasa yang diperoleh dari semua kegiatan perekonomian disuatu daerah.

\section{Pendapatan Asli Daearah (PAD)}

Pendapatan Asli Daerah (PAD) menjadi sumber pendapatan yang didapatkan dari kegiatan dan pengelolaan kekayaan daerah. Pendapatan tersebut terdiri dari pajak, restribusi, dan berbagaoi pendapatan daerah yang benefit.

\section{Dana Alokasi Umum (DAU)}

Dana Alokasi umummerupakan besara dana yang dianggarkan untuk memenuhi kebutuhan umum daerah. Alokasi ini digunakan untuk mengoptimalkan pelayanan masyarakat seperti fasilitas umum, bangunan, jalan dan irigasi.

\section{Sisa Lebih Pembiayaan Anggaran (SILPA)}

Anggaran dinyatakan SILPA apabila pada saat nilai penerimaan dan pengeluaran sebelumnya melampaui nilai PAD. SilPA ini didapatkan dari sisa anggaran yang berlebih pada tahun sebelumnya.

\section{Luas Wilayah}

Luas wilayah merupakan besaran wilayah yang terhitung dan tercatat secara administratif sebagai sebuah sistem pengelolaan kekayaan daerah. Wilayah dapat dilakukan pengelolaan dengan adanya batasan sistem serta dijadikan sebagai aspek funsional. Ukuran luas wilayah ini dihitung menggunakan satuan kilometer $(\mathrm{km})$.

\section{Hubungan antara Pertumbuhan Ekonomi dengan Belanja Modal}

Untuk menghadapi era globalisasi ekonomi, indonesia telah melakukan langkah yang tepat dengan memberikan kebijakan ekonomi daerah yang luas dan bertanggung jawab kepada daerah yang mana hal ini akan memperkuat pertumbuhan ekonomi daerah. Peningkatan Pertumbuhan ekonomi akan bisa dilakukan dengan pengelolaan sumber daya yang tepat dan dengan mengikutsertakan masyarakat dalam pelaksaannya hal ini akan membuka lapangan pekerjaan untuk masyarakat (Suratno, 2010). Setiap daerah memiliki potensi yang berbeda beda yang menyebabkan pertumbuhan ekonominya pun berbeda, yang mana daerah yang memiliki potensi yang bagus investasi modal swasta maupun pemerintah akan berbeda dengan daerah yang lain.

H1: Pertumbuhan ekonomi berpengaruh positif terhadap belanja modal

\section{Hubungan Dana Alokasi Umum dengan Belanja Modal}

Rudi (2017) menyatakan Dana Alokasi Umum memiliki hubungan secara positif dengan belanja modal. Semakin besar dana alokasi umum yang dialokasikan pemerintahan pusat kepada daerah maka semakin tinggi anggaran belanja modal yang dapat digunakan oleh pemerintahan daerah. Kemudian Wimpi (2017) juga mengemukakan bahwa dana alokasi umum berpengaruh positif terhadap belanja modal.

H2 : Dana Alokasi Umum berpengaruh positif terhadap belanja modal 


\section{Hubungan antara Pendapatan Asli Daerah dengan Belanja Modal}

Pendapatan Asli Daerah (PAD) menjadi sumber pendapatan yang didapatkan dari kegiatan dan pengelolaan kekayaan daerah. Pendapatan tersebut terdiri dari pajak, restribusi, dan berbagaoi pendapatan daerah yang benefit. Wandira (2013) berdasarkan hasil penelitiannya menunjukkan bahwa PAD memiliki pengaruh positif belanja modal. Hal ini juga sesuai dengan penelitian yang dilakukan oleh Fiona (2013, Wimpi (2017), Rudi (2017), Made (2018), Widya (2018).

H3: Pendapatan Asli Daerah berpengaruh positif terhadap belanja modal

\section{Hubungan antara Sisa Lebih Pembiayaan Anggaran dengan Belanja modal}

Anggaran dinyatakan SILPA apabila pada saat nilai penerimaan dan pengeluaran sebelumnya melampaui nilai PAD. SilPA ini didapatkan dari sisa anggaran yang berlebih pada tahun sebelumnya. Menurut Engkos Kosim (2017) dan Sandra Okynawa (2018) menyatakan bahwa secara parsial SiLPA memiliki pengaruh yang positif terhadap belanja modal.

H4: Sisa Lebih Pembiayaan Anggaran berpengaruh positif terhadap belanja modal

\section{Hubungan antara Luas Wilayah dengan Belanja Modal}

Luas wilayah merupakan besaran wilayah yang terhitung dan tercatat secara administratif sebagai sebuah sistem pengelolaan kekayaan daerah. Wilayah dapat dilakukan pengelolaan dengan adanya batasan sistem serta dijadikan sebagai aspek funsional. Ukuran luas wilayah ini dihitung menggunakan satuan kilometer $(\mathrm{km})$. Menurut hasil penelitian Nurur Rohmah (2019) dan Bintang Marseno (2020), menyebutkan bahwa Luas Wilayah memiliki pengaruh positif dengan belanja modal.

H5: Luas Wilayah berpengaruh positif terhadap belanja modal

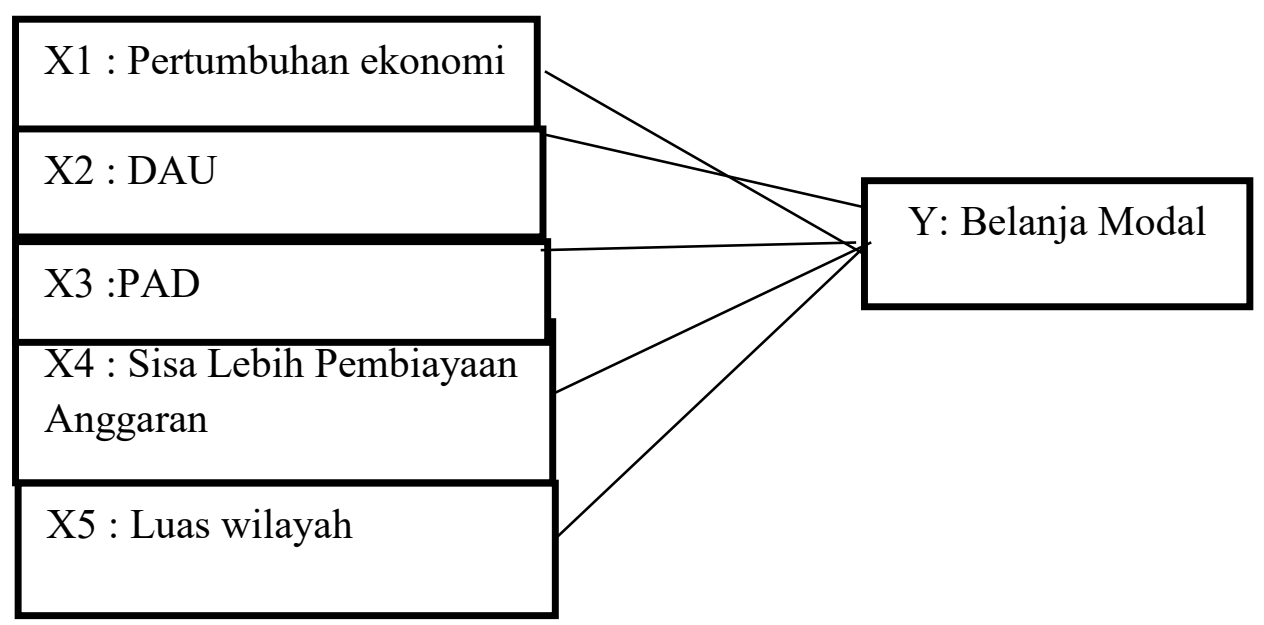

\section{METODE PENELITIAN}

\section{Populasi dan Sampel}

Populasi dalam penelitian ini adalah seluruh pemerintah Kabupaten/Kota Se-Bengkulu 20152019. Teknik penentuan sampel penelitan ini adalah Metode Jenuh. Sampling jenuh menjadikan setiap pupoulasi penelitian menjadi sampel penelitian. Total sampel sebanyak 10 (sepuluh) sampel yang merupakan 9 (sembilan) Kabupaten dan 1 (satu) Kota yaitu Kota Bengkulu. Jadi terdapat 10 sampel untuk setiap tahunnya. Total sampel penelittian ini adalah 50 sampel yang akan menjadi objek penelitian selama 5 tahun periode.

\section{Jenis dan Sumber Data}

Jenis data yang digunakan adalah data sekunder yang berasal dari dokumen Laporan APBD Kabupaten/Kota di Bengkulu periode tahun 2015 sampai 2019. Sumber data penelitian ini 
adalah akses online www.djpk.kemenkeu.go.id. Sedangkan data pertumbuhan ekonomi dan luas wilayah bersumber dari dokumen laporan BPS Provinsi Bengkulu periode tahun tahun 2015 sampai 2019 (www.bengkulu.bps.go.id).

\section{Variabel Penelitian dan Pengukuran \\ Variabel Dependen (Y)}

Belanja modal menurut PP Nomor 71 Tahun 2010 merupakan pengeluaran anggaran dana (uang) agar dapat memenuhi kebutuhan memperoleh aset tetap dengan masa manfaat lebih dar 1 periode akuntansi. Belanja modal dapat berupa pembiayaan memperoleh peralatan, tanah, aset tak berwujud, gedung dan bangunan.

\section{Variabel Independen (X)}

\section{Pertumbuhan Ekonomi}

Pertumbuhan ekonomi sebagai upaya penumbuhan pendapatan perkapita setiap masyarakat dalam suatu periode. Pertumbuhan pendapatan masyarakat akan seiring bertumbuh dengan pertumbuhan daya produksi daerah terhadap setiap sektor pertumbuhan ekonomi daerah. Tingkat pertumbuhan ekonomi dikatakan meningkat tergantung pertumbuhan ekonomi perkapita masyarakat yang juga menjadi faktor keberhasilan pembangunan daerah.

$$
G=\frac{P D R B_{1}-P D R B_{0}}{P D R B_{0}} \times 100 \%
$$

$$
\begin{array}{ll}
\text { Keterangan : } \\
\mathrm{G} & =\text { Tingkat pertumbuhan ekonomi } \\
\mathrm{PDRB} 1 & =\text { PDRB ADHK tahun uji } \\
\mathrm{PDRB} 0 & =\text { PDRB ADHK sebelum tahun uji }
\end{array}
$$

\section{Dana alokasi umum (DAU)}

Dana Alokasi Umum (DAU) di dapat dari alokasi dana APBN sebagai upaya pemerataan keuangan daerah.

\section{PAD}

Pendapatan asli daerah menjadi penerimaan daerah yang bersumber dari pengelolaan kekayaan daerah yang dihitung menggunakan rumus.

\section{$\mathbf{P A D}=\mathbf{H P D}+\mathbf{R D}+\mathbf{P L P D}+\mathbf{L P S}$}

Keterangan :

$$
\begin{aligned}
& \text { PAD }=\text { Pendapatan Asli Daerah } \\
& \text { HPD }=\text { Hasil Pajak Daerah } \\
& \text { RD }=\text { Retribusi Daerah } \\
& \text { PLPD }=\text { Pendapatan dari Laba Perusahaan Daerah } \\
& \text { LPS }=\text { Lain-lain Pendapatan yang Sah }
\end{aligned}
$$

\section{SILPA}

Sisa Lebih Pembiayaan Anggaran (SILPA) merupakan selisih yang terjadi antara realisasi pendapatan LRA dan belanja serta penerimaan dan pengeluaran selama satu (1) periode pelaporan. Menentukan SILPA dalam Laporan Realisasi Anggaran dihitung berdasarkan jumlah total pemasukan daerah dikurangi dengan jumlah total pengeluaran daerah. Total 
pemasukan daerah terdiri dari penerimaan PAD, dana perimbangan (DAU, DBH, DAK), penerimaan lain-lain pendapatan daerah yang sah, dan pembiayaan daerah. Sedangkan total pengeluaran daerah mencakup belanja daerah yang terdiri dari belanja langsung dan belanja tidak langsung.

\section{Luas Wilayah}

Luas wilayah merupakan besaran wilayah yang terhitung dan tercatat secara administratif sebagai sebuah sistem pengelolaan kekayaan daerah. Wilayah dapat dilakukan pengelolaan dengan adanya batasan sistem serta dijadikan sebagai aspek funsional. Ukuran luas wilayah ini dihitung menggunakan satuan kilometer $(\mathrm{km})$.

\section{Teknik Analisis data}

\section{Statistik Deskriptif}

Uji Asumsi Klasik

a. Uji Normalitas

b. Uji Multikolinearitas

c. Uji Autokorelasi

d. Uji Heteroskedastisitas (uji Glejser)

e. Uji Autokorelasi

\section{Metode Regresi Linier Berganda}

\section{HASIL DAN PEMBAHASAN \\ Hasil olah data}

TABEL 2

\section{Hasil Statistik Deskriptif}

$\begin{array}{lcccccc} & \text { BM } & \text { PE } & \text { DAU } & \text { PAD } & \text { SILPA } & \text { LW } \\ \text { Mean } & 11.23960 & 7.078000 & 11.67100 & 10.54420 & 10.64200 & 3.165000 \\ \text { Median } & 11.21500 & 6.665000 & 11.68500 & 10.59000 & 10.67000 & 3.245000 \\ \text { Maximum } & 11.50000 & 9.510000 & 11.83000 & 11.26000 & 11.22000 & 3.640000 \\ \text { Minimum } & 10.92000 & 6.370000 & 10.69000 & 7.300000 & 9.630000 & 2.180000 \\ \text { Std. Dev. } & 0.131443 & 0.849360 & 0.161223 & 0.549063 & 0.356491 & 0.407963\end{array}$

(Sumber: Data Olahan Eviews 9 tahun 2021)

Berdasarkan tabel 7 diatas, variabel BM sebagai variabel dependen memiliki rata-rata 11.23960 dengan standar deviasi 0.131443. Nilai maksimum sebesar 0.131443 dan nilai minimum sebesar 11.50000. Variabel pertumbuhan ekonomo(PE) sebagai variabel independen memiliki rata-rata 7.078000 dengan standar deviasi 0.849360 . Nilai maksimum sebesar 9.510000 dan nilai minimum sebesar 6.370000. Variabel dana alokasi umum (DAU) sebagai variabel independen memiliki rata-rata 11.67100 dengan standar deviasi 0.161223 . Nilai maksimum sebesar 11.83000 dan nilai minimum sebesar 10.69000.

Variabel pendapatan asli daerah (PAD) sebagai variabel independen memiliki ratarata 10.54420 dengan standar deviasi 0.549063 . Nilai maksimum sebesar 11.26000 dan nilai minimum sebesar 7.300000. Variabel sisa lebih pembiayaan anggaran (SILPA) sebagai variabel independen memiliki rata-rata 10.64200 dengan standar deviasi 0.356491 . Nilai maksimum sebesar 11.22000dan nilai minimum sebesar 9.630000. Variabel luas wilayah (LW) sebagai variabel independen memiliki rata-rata 3.165000 dengan standar deviasi 0.407963 . Nilai maksimum sebesar 3.640000dan nilai minimum sebesar 2.180000. 


\section{Analisis Induktif}

Analisis Model Regresi Panel

Estimasi Pembuatan Model Regresi Panel pada Model Penelitian

\section{a. Chow test atau Likelyhood Test}

Hasil Chow Test atau Likelyhood Test untuk analisis model hipotesis pertama, yaitu pengaruh perubahan ekonomi terhadap belanja modal sebagai berikut:

TABEL 3

Hasil Chow Test atau Likelyhood Test

\begin{tabular}{|llrc|}
\hline \multicolumn{3}{|c|}{ Cross-section Chi-square } \\
\hline \multicolumn{1}{|c}{ Model Penelitian } & Statistic & d.f & Prob \\
\cline { 1 - 2 } \cline { 3 - 4 } Cross-section F & 3.058829 & $(9,35)$ & 0.0083 \\
Cross-section Chi-square & 29.01449 & 9 & 0.0006 \\
\hline
\end{tabular}

(Sumber: Data Olahan Eviews9 tahun 2020)

Berdasarkan hasil Chow-Test dengan menggunakan eviews9, Nilai probabilitas model yang digunakan mengahasilkan nilai lebih kecil dibanding level signifikansinya $(\alpha=0,05)$. Maka H0 untuk model ini ditolak dan Ha dierima sehingga estimasi yang lebih baik untuk digunakan dalam model ini adalah Fix Effect Model (FEM). Untuk itu perlu dilanjutkan ke Hausman Test.

\section{b. Hausman Test}

Berdasarkan hasil Chow Test atau Likelyhood Test pada Tabel 8, maka dibutuhkan uji Hausman pada persamaan regresi untuk hipotesis. Adapun hasil Hausman test adalah sebagai berikut:

TABEL 4

Hasil Hausman Test

Cross-section random

\begin{tabular}{cccc}
\hline $\begin{array}{c}\text { Model } \\
\text { Penelitian }\end{array}$ & $\begin{array}{c}\text { Chi-Sq. } \\
\text { Statistic }\end{array}$ & $\begin{array}{c}\text { Chi-Sq. } \\
\text { d.f }\end{array}$ & Prob \\
$\begin{array}{c}\text { Cross-section } \\
\text { random }\end{array}$ & 12.36297 & 4 & 0.0148 \\
& & &
\end{tabular}

(Sumber: Data Olahan Eviews9 tahun 2021)

Berdasarkan hasil Hausman Test dengan menggunakan eviews9, Nilai probabilitas Model yang diperoleh sebesar 0.0148. Nilai probabilitasnya yang diperoleh lebih kecil dari level signifikansinya $(\alpha=0,05)$, maka $\mathrm{H} 0$ untuk model ini ditolak dan Ha diterima. Model estimasi yang saat ini tepat digunakan dalam model ini adalah Fix Effect Model (FEM), sehingga perlu dilakukan uji asumsi klasik terhadap model tersebut.

\section{c.Model Regresi Panel}

Berdasarkan hasil estimasi model regresi pada Chow Test (Tabel 8) dan Hausman Test (Tabel 9), maka digunakan pendekatan Fix Effect Model (FEM) untuk mengestimasi pengaruh variabel dependen terhadap variabel independen. Adapun hasil regresi panel dengan menggunakan pendekatan Fix Effect Model (FEM) dapat dilihat pada Tabel 10. 
TABEL 5

Hasil Regresi Panel

\begin{tabular}{|c|c|c|c|c|}
\hline Variabel & Koef. & Prediksi & t-stat & Prob. \\
\hline Konstanta & $-7.18 \mathrm{E}+14$ & $(-)$ & -0.44443 & 0.6595 \\
\hline Pertumbuhan ekonomi & -37.80375 & $(-)$ & -2.39818 & 0.0219 \\
\hline $\begin{array}{l}\text { DAU } \\
\text { (Dana Alokasi Umum ) }\end{array}$ & 0.07084 & $(+)$ & 0.624596 & 0.5363 \\
\hline $\begin{array}{l}\text { PAD } \\
\text { (Pendapatan Asli Daerah) }\end{array}$ & -0.284211 & $(-)$ & -0.57386 & 0.5697 \\
\hline $\begin{array}{l}\text { Sisa Lebih Pembiayaan } \\
\text { Anggaran }\end{array}$ & -0.190452 & $(-)$ & -0.60753 & 0.5474 \\
\hline Luas Wilayah & $3.60 \mathrm{E}+11$ & $(+)$ & 0.444537 & 0.6594 \\
\hline Adj R-Square & & 0.357201 & & \\
\hline F-Statistic & & 2.944936 & & \\
\hline
\end{tabular}

(Sumber: Data Olahan Eviews 9 tahun 2021)

Uji Asumsi Klasik

Uji Normalitas

Gambar 1. Hasil Uji Normalitas

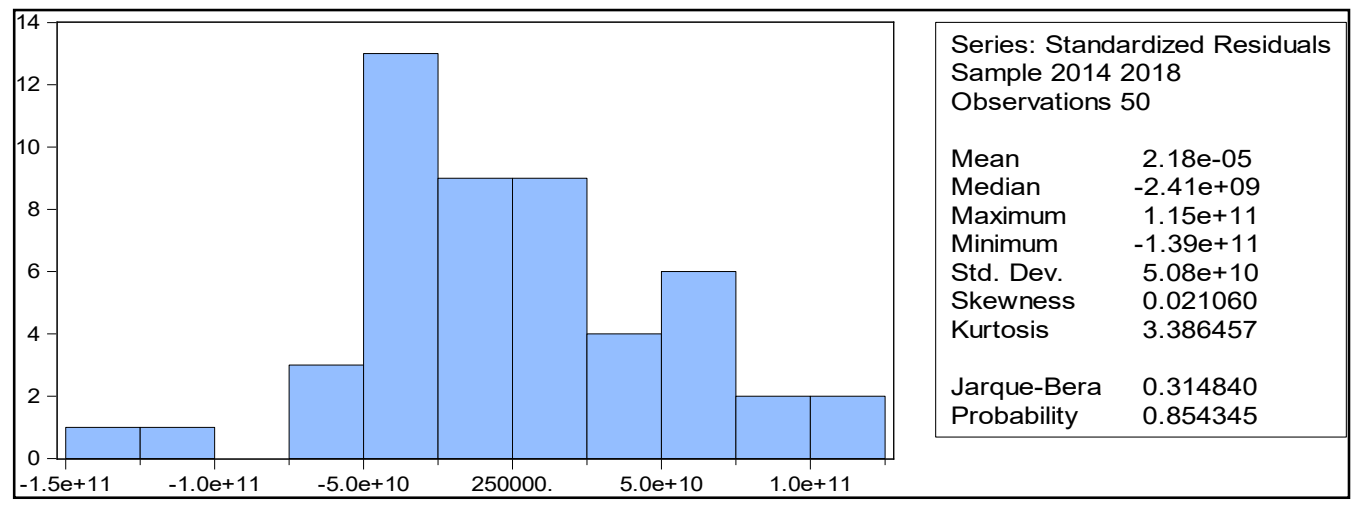

Uji Multikolinieritas

Tabel 6

Hasil Uji Multikolinieritas

\begin{tabular}{|lrrrrr|}
\hline \multicolumn{5}{c}{ UJI MULTIKOLINEARITAS } \\
& PE & DAU & PAD & SILPA & \multicolumn{1}{l|}{ LW } \\
PE & 1 & -0.05298 & -0.06992 & 0.210063 & 0.130834 \\
DAU & -0.05298 & 1 & 0.774367 & 0.266052 & 0.079571 \\
PAD & -0.06992 & 0.774367 & 1 & 0.109249 & -0.12475 \\
SILPA & 0.210063 & 0.266052 & 0.109249 & 1 & 0.364115 \\
LW & 0.130834 & 0.079571 & -0.12475 & 0.364115 & 1 \\
\hline
\end{tabular}

(Sumber: Data Olahan Eviews9 Tahun 2021) 


\section{Uji Heteroskedastisitas}

\section{Tabel 7 \\ Hasil Uji Heteroskedastisitas}

\begin{tabular}{|lrrrr|}
\hline \multicolumn{4}{|l}{ Heteroskedasticity Test: White } \\
\hline \hline \multicolumn{1}{r}{ Variable } & Coefficient & \multicolumn{1}{l|}{ Std. Error } & t-Statistic & Prob. \\
\hline \hline C & $2.36 \mathrm{E}+10$ & $2.28 \mathrm{E}+10$ & 1.037292 & 0.3053 \\
PE & -13.6753 & 8.3499 & -1.63778 & 0.1086 \\
DAU & -0.03119 & 0.061994 & -0.50311 & 0.6174 \\
PAD & 0.316579 & 0.18915 & 1.673692 & 0.1013 \\
SILPA & -0.1291 & 0.112716 & -1.14532 & 0.2583 \\
LW & 12403219 & 3501935 & 3.541818 & 0.001 \\
\hline \hline R-squared & 0.282869 & Mean dependent var & $3.91 \mathrm{E}+10$ \\
Adjusted R-squared & 0.201376 & S.D. dependent var & $3.19 \mathrm{E}+10$ \\
\hline
\end{tabular}

(Sumber: Data Olahan Eviews 9 Tahun 2021)

Heteroskedastisitas digunakan untuk menguji apakah dalam sebuah model regresi terjadi ketidaksamaan varians dalam residual dari suatu pengamatan kepengamatan lainnya. Untuk mendeteksi adanya heteroskedastisitas digunakan uji White. Apabila nilai probabilitas ChiSquare dari R-Square $>$ a (0.05) maka tidak terdapat gejala heteroskedastisitas. Berdasarkan tabel 4.12 dibawah, probabilitas Chi-Square dari Obs*R-Square adalah 0.282869 yang $>0.05$ yang menunjukkan tidak ada gejala heteroskedastisitas.

\section{PEMBAHASAN}

\section{Pengaruh Pertumbuhan Ekonomi Terhadap Belanja Modal.}

Hipotesis pertama pada penelitian ini yakni variabel Pertumbuhan ekonomi berpengaruh positif terhadap belanja modal. Semakin meningkat pertumbuhan ekonomi suatu daerah, maka juga akan meningkatkan nilai belanja modal daerah. Namun berdasarkan hasil penelitian ini, nilai pertumbuhan ekonomi di Provinsi Bengkulu tidak meningkatkan nilai belanja modal daerah. Hasil ini memiliki nilai koefisien bernilai negative sebesar -37.80375 nilai probabilitas sebesar 0.0219 dan signifikan pada $\alpha 5 \%$. Hal ini berarti pertumbuhan ekonomi berkontribusi negatif dan berpengaruh signifikan terhadap belanja modal, karena nilai prob $<0,05$, yaitu $0.0219<0,05$. Hal tersebut menunjukkan bahwa semakin besar pertumbuhan ekonomi tidak berpengaruh terhadap belanja modal. Temuan ini tidak mendukung hipotesis pertama.

Penelitian Marseno (2020) yang menunjukkan bahwa pertumbuhan ekonomi tidak berpengaruh terhadap belanja modal. Eka Sridawati Purba (2020) yang mana hasil penelitian bahwa pertumbuhan ekonomi tidak berpengaruh terhadap belanja modal. Sejalan dengan hasil penelitian bahwa Pertumbuhan ekonomi yang baik atau meningkat tidak akan berdampak besar terhadap alokasi belanja modal pada pemerintah kabupaten/kota Bengkulu.

\section{Pengaruh Dana Alokasi Umum terhadap Belanja Modal.}

Hipotesis kedua pada penelitian ini adalah Dana Alokasi Umum berpengaruh positif terhadap belanja modal. Semakin besar dana alokasi umum yang dianggarkan untuk suatu daerah maka akan meningkatkan besaran belanja modal daerah tersebut. Namun, berdasarkan hasil penelitian ini, niai dana alokasi umum tidak meningkatkan nilai belanja modal Provinsi Bengkulu. Nilai koefisien DAU bernilai positif sebesar 0.07084 nilai dan probabilitas sebesar 0.5363 dan signifikan pada $\alpha 5 \%$. Hal ini berarti DAU tidak berpengaruh terhadap belanja modal, karena nilai prob $>0,05$, yaitu $0.5363>0,05$. Hasil ini menjelaskan bahwa kabupaten 
dan kota yang mendapatkan DAU yang besar tidak memiliki belanja modal yang besar. Hasil penelitian ini tidak mendukung hipotesis kedua.

penelitian Annisa (2019) hasil penelitiannya menyatakan bahwa dana alokasi umum tidak berpengaruh positif terhadap belanja modal pada Kabupaten/Kota di Jawa Barat. Aditiya (2017) Dana Alokasi Umum (DAU) tidak berpengaruh positif terhadap Belanja Modal pada Kabupaten dan Kota di Provinsi Jawa Tengah, disebabkan Dana Alokasi Umum (DAU) yang diterima oleh kabupaten dan kota di Provinsi Jawa Tengah dalam prakteknya dimanfaatkan untuk belanja operasi yang terdiri dari belanja pegawai, belanja barang, belanja subsidi, belanja hibah, belanja bantuan sosial, belanja bantuan keuangan.

\section{Pendapatan Asli Daerah Berpengaruh Positif Terhadap Belanja Modal.}

Hipotesis ketiga pada penelitian ini adalah pendapatan asli daerah berpengaruh positif terhadap belanja modal. Semakin besar nilai pendapatan asli daerah, maka akan meningkatkan nilai belanja modal daerah tersebut. Namun, berdasarkan hasil penelitian ini, nilai pendapatan asli daerah tidak meningkatkan nilai belanja modal pada Provinsi Bengkulu. Nilai koefisien PAD bernilai negatif sebesar -0.284211 dan nilai probabilitas sebesar 0.5697 dan signifikan pada $\alpha 5 \%$. Hal ini menunjukkan PAD tidak berpengaruh terhadap belanja modal, karena nilai prob $>0,05$, yaitu $0.5697>0,05$. Hasil ini menjelaskan bahwa Kabupaten dan kota dengan PAD yang besar tidak memiliki belanja modal yang besar. Hal ini disebabkan karena PAD lebih banyak digunakan untuk membiayai belanja lain, seperti belanja rutin/belanja operasional. Hasil penelitian ini tidak mendukung hipotesis ketiga.

penelitian ini sejalan dengan penelitian yang dilakukan oleh Rendy Armando Kakasih (2018) yang menyatakan bahwa Pendapatan Asli Daerah tidak pengaruh positif terhadap Belanja Modal. Hal ini berarti bahwa Kabupaten dan kota dengan Pendapatan Asli Daerah yang besar tidak memiliki belanja modal yang besar, disebabkan karena Pendapatan Asli Daerah lebih banyak digunakan untuk membiayai belanja lain, seperti belanja rutin/belanja operasional. Hal ini dapat diartikan bahwa semakin tinggi Pendapatan Asli Daerah maka pengeluaran pemerintah atas Belanja Modal belum tentu juga akan semakin tinggi.

\section{Pengaruh Sisa Lebih Pembiayaan Anggaran Terhadap Belanja Modal}

Hipotesis keempat pada penelitian ini adalah sisa lebih pembiayaan anggaran berpengaruh positif terhadap belanja modal. Semakin besar sisa lebih pembiayaan anggaran maka akan meningkatkan nilai belanja modal suatu daerah. Namun, berdasarkan hasil penelitian ini, nilai sisa lebih pembiayaan anggaran tidak meningkatkan nilai belanja modal daerah Provinsi Bengkulu. Nilai koefisien bernilai negatif sebesar -0.190452 dan nilai probabilitas sebesar -0.60753 dan signifikan pada $\alpha 5 \%$. Hal ini berarti SILPA tidak berpengaruh terhadap belanja modal, karena nilai prob $>0,05$, yaitu $-0.60753>0,05$. Terbentuknya SILPA hanya jika adanya kelebihan atau surplus pada APBD dimana penerimaan lebih besar dari pada pengeluaran. Ada atau tidaknya SILPA dapat dilihat dari besar atau kecilnya tingkat belanja daerah. Hasil penelitian ini tidak mendukung hipotesis keempat.

Penelitian ini sejalan dengan Wahyu Hikmah (2019), yang menyatakan SILPA tidak berpengaruh signifikan terhadap alokasi belanja modal. hal ini dapat diartikan bahwa semakin tinggi SILPA maka pengeluaran pemerintah atas belanja modal belum tentu juga akan semakin tinggi. Pada penelitian ini menunjukan hasil yang tidak signifikan disebabkan Sisa Lebih Pembiayaan Anggaran (SILPA) dan besar kecilnya sangat tergantung pada tingkat belanja yang dilakukan pemerintah daerah serta kinerja pendapatan daerah (Widya, 2018). Terjadinya Sisa Lebih Pembiayaan Anggaran (SILPA) memberikan indikator positif guna meningkatnya pembiayaan di daerah dalam memenuhi kebutuhan belanja modal. 


\section{Pengaruh Luas Wilayah terhadap Belanja Modal}

Hipotesis kelima pada penelitian ini adalah luas wilayah berpengaruh positif terhadap belanja modal. Semakin besar luas wilayah suatu daerah, maka akan semakin meningkatkan besar belanja modal daerah. Hal ini disebabkan daerah dengan wilayah yang lebih luas tentulah membutuhkan sarana dan prasarana yang lebih banyak sebagai syarat untuk pelayanan publik bila dibandingkan dengan daerah yang wilayah yang tidak begitu luas. Namun, berdasarkan hasil penelitian ini, nilai luas wilayah tidak meningkatkan besaran belanja modal daerah Provinsi Bengkulu. Nilai koefisien bernilai positif sebesar $3.60 \mathrm{E}+11$ nilai probabilitas sebesar 0.6594 dan signifikan pada $\alpha 5 \%$. Hal ini berarti luas wilayah tidak berpengaruh terhadap belanja modal, karena nilai prob $>0,05$, yaitu $-0.6594>0,05$. Hasil penelitian ini tidak mendukung hipotesis kelima.

Penelitian ini sejalan dengan Devanthara Adhi Nugraha (2018) yang mana luas wilayah tidak berpengaruh terhadap belanja modal, hal ini membuktikan semakin luas suatu wilayah tidak mempengaruhi besarnya belanja modal daerah tersebut. Pada penelitian ini menunjukan hasil yang tidak signifikan disebabkan Alokasi belanja modal pemerintah tidak hanya memperhatikan luas wilayah pemerintah, tetapi juga melihat skala prioritas. Sehingga walaupun suatu pemerinta memiliki wilayah yang luas bukan berarti pemerintah akan mengalokasikan anggarannya untuk belanja modal. Pemerintah harus melihat kebutuhan yang paling penting dalam daerahnya.

\section{SIMPULAN, KETERBATASAN DAN SARAN \\ Simpulan}

Berdasarkan hasil penelitian dan pengujian hipotesis yang telah dilakukan sebelumnya, maka kesimpulan penelitian ini adalalah Pertumbuhan ekonomi Dana Alokasi Umum (DAU), Pendaptan Asli Daerah (PAD), Sisa Lebih Pembiayaan Anggaran (SILPA) dan Luas wilayah tidak berpengaruh terhadap Belanja Modal.

\section{Keterbatasan}

Penelitian ini hanya menggunakan variabel Pertumbuhan ekonomi, Dana Alokasi Umum (DAU), Pendaptan Asli Daerah (PAD), Sisa Lebih Pembiayaan Anggaran (SILPA), Luas wilayah sebagai variabel independen sehingga memberikan peluang bagi peneliti selanjutnya untuk menggunakan variabel lain, Data penelitian yang digunakan hanya 5 tahun yaitu tahun 2015 -2019,Dalam penelitian ini seluruh variabel independen tidak berpengaruh terhadap variabel dependen sehingga dalam penelitian ini belum dapat menjelaskan hal apa saja yang mempengaruhi Belanja Modal.

\section{Saran}

Bagi peneliti selanjutnya 1) sebaiknya menambahkan variabel lain yang dianggap dapat mempengaruhi Belanja Modal, 2) Bagi peneliti selanjutnya dapat menggunakan data terbaru dan menggunakan pengujian lain.

\section{DAFTAR PUSTAKA}

Aditya, Nanda Yoga dan Novi Dirgantari. 2017. Pengaruh Pendapatan Asli Daerah (PAD), Dana Alokasi Umum (DAU), Dana Alokasi Khusus (DAK) Dan Sisa Lebih Pembiayaan Anggaran (SILPA) Terhadap Belanja Modal Pada Kabupaten Dan Kota Di Jawa Tengah Tahun 2013- 2015.KOMPARTEMEN, Vol. XV No.1, Maret 2017. 
Adyatma, Erdi dan Oktaviani, Rahmawati Meita. 2015. "Pengaruh Pendapatan Asli Daerah dan Dana Alokasi Umum Terhadap Belanja Modal Dengan Pertumbuhan Ekonomi Sebagai Pemoderasi”. ISSN 1979-4878, Volume 4 Nomor 2 Nopember 201

Anjani, Eka Sintala Dewi \& Akram. 2015. Hubungan PAD, Belanja Modal dan Kinerja Keuangan Pemerintah Daetah di Nusa Tenggara Barat. Vol 11, No. 1 Hal 1-21.

Annisa, Wahyu Hikmah. Pengaruh Dana Alokasi Khusus (Dak), Dana Alokasi Umum (Dau), Pendapatan Asli Daerah (Pad), Sisa Lebih Pembiayaan Anggaran (SILPA), Luas Wilayah Dan Kinerja Keuangan Terhadap Belanja Modal (Studi Pada Pemerintah Daerah Kabupaten/Kota Di Provinsi Jawa Tengah). Diss. Universitas Widya Dharma, 2019.

Ceunfin, S., D. Prajitno., P. Suryanto., dan E. T. S. Putra. 2017. Penilaian Kompetisi dan Keuntungan Hasil Tumpangsari Jagung Kedelai di Bawah Tegakan Kayu Putih. Jurnal Pertanian Konservasi Lahan Kering.

Darwanto dan Yustikasari. 2007. Pengaruh Pertumbuhan Ekonomi, Pendapatan Asli Daerah dan Dana Alokasi Umum Terhadap Pengalokasian Belanja Modal. Simposium Nasional Akuntansi X Makasar 26-28 juli 2007.

Halim, Abdul. (2012). Akuntansi Keuangan Daerah, Penerbit Salemba Empat, Jakarta.

Irsyadi. 2014. Analisis Faktor-Faktor Yang Mempengaruhi Alokasi Belanja Modal (Studi Empiris Pada Kabupaten/Kota Di Provinsi Jawa Tengah). Universitas Muhammadiyah Surakarta

Jensen, M. C and Meckling, W.H. 1976. Theory of the Firm : Managerial Behavior, Agency Costs and Ownership Structure . Journal of Financial Economics, Oktober, 1976, V. 3, No. 4, pp. 305-360. Avalaible from: http://papers.ssrn.com

Kakasih, Rendy Armando dan George M.V. Kawung, Steeva Y.L Tumangkeng. (2018). Pengaruh Pendapatan Asli Daerah dan Dana Alokasi Umum Terhadap Belanja Modal Pada Kabupaten dan Kota di Provinsi Sulawesi Utara Periode 2009-2016. Jurnal Berkala Ilmiah Efisiensi. Vol.18 No. 02.

Keswando, Robin, Suharno, Djoko Keistiano 2016. Pengaruh pendapatan asli daerah, dana alokasi umum, dana alokasi khusus, dal luas wilayah terhadap alokasi belanja modal studi empiris di provinsi jawa timur. Program studi Akuntansi Fakultas ekonomi Universitas Slamet Riyadi Surakarta

Kosim, Engkos. 2017. Pengaruh Pendapatan Asli Daerah (PAD), Dana Alokasi Umum (DAU) Dan Sisa Lebih Pembiayaan Anggaran (SILPA) Terhadap Anggaran Belanja Modal Pada Pemerintah Kota Banjar. journal of managementReview ISSN-P : 2580-4138 ISSN-E 2579-812X.

Mardiasmo. (2014). Akuntansi Sektor Publik. Yogyakarta: Penerbit ANDI.

Marseno, Bintang, and Erly Mulyani. "Pengaruh Pertumbuhan Ekonomi, Pendapatan Asli Daerah (PAD), Jumlah Penduduk Dan Luas Wilayah Terhadap Belanja Modal Pemerintah Daerah." JURNAL EKSPLORASI AKUNTANSI 2.4 (2020): 34523467.

MUCHSON, Mohammad, and M. Ec Boediono. Faktor-faktor penyebab kemiskinan di pedesaan:: Kasus desa Salamrejo Kabupaten Kulon Progo. Diss. [Yogyakarta]: Universitas Gadjah Mada, 1985.

Muflikhah, Muflikhah, Bambang Rusdiarso, Edy Giri Rachman Putra, and Nuryono Nuryono. "Modification of silica coated on iron sand magnetic material with chitosan for adsorption of Au (III)." Indonesian Journal of Chemistry 17, no. 2 (2017): 264273. 
Nainggolan, Benny Rojeston Marnaek. (2018). Pengaruh Pendapatan Asli Daerah dan Dana Perimbangan Terhadap Belanja Modal Dengan Sisa Lebih Perhitungan Anggaran Sebagai Variabel Moderasi Pada Pemerintah Kota dan Kabupaten Provinsi Sumatera Utara. Jurnal AKRAB JUARA Yayasan Akrab Pekanbaru.

Nofrizal, Egi, Akhsanul Haq, and Sigit Edi Surono. "Pengaruh Pertumbuhan Ekonomi Dan Pendapatan Asli Daerah Terhadap Belanja Modal Pada Kabupaten/Kota Di Provinsi Jawa Barat Periode 2011-2015." Jurnal Online Mahasiswa (JOM) Bidang Akuntansi 2.2 (2017).

Nora, Rizky. Prita S.D.S. dan Indriyani, R. (2015). Pengaruh Pendapatan Asli Daerah (PAD), Dana Perimbangan, Sisa Lebih Pembiayaan Anggaran, dan Luas Wilayah terhadap Belanja Modal Pada Pemerintah Daerah Kabupaten/Kota Provinsi Jawa Timur. Artikel Ilmiah Mahasiswa. Universitas Jember.

Nurharibnu Wibisono \& Arini Wildaniati.2016. Pengaruh Pertumbuhan Ekonomi, Pad, Dau, SILPA Dan Luas Wilayah Terhadap Alokasi Anggaran Belanja Modal. Universitas Merdeka Madiun

Nurzen, Miardi. 2016. Pengaruh Pertumbuhan Ekonomi, Pendapatan Asli Daerah Dan Dana Alokasi Umum Terhadap Belanja Modal. Vol 5 ISSN 2460-0585.

Nurzen, Miardi. 2016. Pengaruh Pertumbuhan Ekonomi, Pendapatan Asli Daerah Dan Dana Alokasi Umum Terhadap Belanja Modal. Vol 5 ISSN 2460-0585.

Priambudi, Wimpi. (2017). Pengaruh Pendapatan Asli Daerahdan Dana Alokasi Umum Terhadap Belanja ModalPada Kabupaten dan Kota di Pulau Jawa Tahun 2013. Vol.06. No 01.

Priambudi, Wimpi. 2017. "Pengaruh Pendapatan Asli Daerah Dan Dana Alokasi Umum Terhadap Belanja Modal Pada Kabupaten Dan Kota Di Pulau Jawa Tahun 2013, Jurnal Nominal”, $\quad$ Vol. $4 \quad$ No. 1 , dalam http://eprints.uny.ac.id/38918/1/skripsi_wimpi\%20priambudi_12812141 018.pdf, diakses 30 Agustus 2018.

Purwanto, Fiona Puspita Devi. (2013). Pengaruh Pertumbuhan Ekonomi, Pendapatan Asli Daerah (PAD), dan Dana Alokasi Umum (DAU) Terhadap Belanja Modal (Studi Kasus Pada Kabupaten dan Kota di Provinsi Jawa Tengah Tahun 2008-2011). Skripsi. Universitas Negeri Yogyakarta.

Riviando, Adel; Agustin, Henri; Halmawati. (2019). Pengaruh Pendapatan Asli Daerah, Dana Alokasi Umum, dan Dana Alokasi Khusus terhadap Indek Pembangunan Manusia dengan Belanja Modal Sebagai Variabel Intervening. Jurnal Eksplorasi Akuntansi. 1(1). Seri A. 1-17.

Putra, Ferdian. (2017). Pengaruh Desentralisasi Fiskal, Luas Wilayah, dan Sisa Lebih Pembiaayaan Anggaran Terhadap Pengalokasian Belanja Modal. ejournal unp. Vol 5. No 1 : Seri C

Rochmatullah, Mahameru Rosy, Rudy Hartanto, dan Atwal Arifin, 2016. "Determinating The Value of Capital Expenditure Allocation in Indonesia Local Goverment", Jurnal Ekonomi Pembangunan, Volume 2 hal 152-166

Rohmah, Nurur, and Ikhsan Budi Riharjo. "Pengaruh Pendapatan Asli Daerah, Dana Perimbangan Dan Luas Wilayah Terhadap Belanja Modal (Studi Pada Kabupaten/Kota Se Privinsi Jawa Timur Tahun 2013-2017)." Jurnal Ilmu dan Riset Akuntansi (JIRA) 8.6 (2019).

Sandra Okynawa . 2016. Pengaruh Pendapatan Asli Daerah (Pad), Dana Alokasi Umum (Dau), Dan Sisa Lebih Pembiayaan Anggaran (SILPA) Terhadap Belanja Modal Kabupaten/Kota Se-Jawa Timur (Apbd Tahun Anggaran 2016). Program Studi Akuntansi, Fakultas Ekonomika dan Bisnis, Universitas Kanjuruhan, Malang. 
Sari, Desak Gede Yudi Atika. (2017). Pengaruh Pertumbuhan Ekonomi, Pendapatan Asli Daerah, Dana Perimbangan, dan Sisa Lebih Pembiayaan Anggaran Terhadap Alokasi Belanja Modal Kabupaten/ Kota Se-Bali. Kumpulan Riset Akuntansi Universitas Mahasaraswati. Vol. 9. No. 1

Sari, Desak Made Mya Yudia dan Dewa Gede Wirama. (2018). Pengaruh PAD, DAU Dan DAK Pada Alokasi Belanja Modal dengan Pendapatan Per Kapita Sebagai Pemoderasi. E-Jurnal Akuntansi Universitas Udayana. Vol. 22. No.3.

Setiyani, Rita Devi. 2015. Pengaruh Dana Alokasi Umum (DAU), Pendapatan Asli Daerah (PAD), Sisa Lebih Pembiayaan Anggaran (SILPA) dan Luas Wilayah terhadap Belanja Modal Studi Empiris pada Kabupaten di Karesidenan Pati Periode 20092013. Universitas Muhammadiyah Surakarta.

Simatupang, M. "Pengaruh Sisa Lebih Pembiayaan Anggaran (SILPA), Tingkat Kemandirian Keuangan Daerah, Luas Wilayah, dan Kepadatan Penduduk Terhadap Pengalokasian Belanja Modal Pada Pemerintahan Daerah (Studi Pada Kabupaten/Kota di Provinsi Sumatera Utara)." (2018).

Sukimo, Sadono. (2015). Makro Ekonomi Teori Pengantar. Edisi 1. Cetakan 21. Jakarta: Rajawali Pcrs

Sukirno, Sadono. "Makroekonomi: Teori Pengantar (edisi pertama)." Jakarta: Raja Grafindo (1991).

uratno, Putro. 2010. Pengaruh Pertumbuhan Ekonomi, Pendapatan Asli Daerah dan Dana Alokasi Umum terhadap Pengalokasian Anggaran Belanja Modal (study kasus kab/kota di provinsi Jawa tengah). Sustainable Development. Vol. 4 No. 3. Juni 2013.

Wandira, Arbie Gugus. 2013. Pengaruh Pendapatan Asli Daerah (PAD), Dana Alokasi Umum (DAU), Dana Alokasi Khusus (DAK), Dan Dana Bagi Hasil (DBH) Terhadap Pengalokasian Belanja Modal (Studi Empiris pada Pemerintah Provinsi se Indonesia tahun 2012). Skripsi. Universitas Negeri Semarang.

Yana, Widya. (2018). Pengaruh PAD, DAU, DBH, dan DOK Terhadap Belanja ModalDengan SILPA sebagai Variabel Pemoderasi Pada Pemerintah Kabupaten/Kota di Provinsi Aceh.Skripsi. Universitas Sumatera UtaraRepositori Institusi USU.

Yovita, Farah Marta dan Dwi Cahyo Utomo. (2011). Pengaruh Pertumbuhan Ekonomi,,Pendapatan Asli Daerah, dan Dana Alokasi Umum Terhadap Pengalokasian Anggaran Belanja Modal (Studi Empiris Pada Pemerintah Provinsi Se Indonesia Periode 2008 - 2010). Skripsi. Fakultas Ekonomi Universitas Diponegoro.

Yovita, Farah Marta dan Dwi Cahyo Utomo. (2011). Pengaruh Pertumbuhan Ekonomi,,Pendapatan Asli Daerah, dan Dana Alokasi Umum Terhadap Pengalokasian Anggaran Belanja Modal (Studi Empiris Pada Pemerintah Provinsi Se Indonesia Periode 2008 - 2010). Skripsi. Fakultas Ekonomi Universitas Diponegoro. 